of labour strategy for transnational solidarity. Hopefully, scholars will meet this challenge with the same degree of verve and insight as that displayed by Peter Cole.

\title{
Stefano Bellucci
}

International Institute of Social History PO Box 2 169, 1000 CD Amsterdam, The Netherlands

E-mail: sbe@iisg.nl

doi:10.1017/S0020859019000658

Stutje, Jan Willem. Hendrik de Man. Een man met een plan. Polis, Kalmthout $2018.230 \mathrm{pp}$. Ill. $€ 35.00$.

Hendrik de Man (1885-1953) is one of the most-studied Belgian socialist leaders: since the I 970 s, several books and articles have been published on this theorist of socialism. An association in Flanders (the Dutch-speaking part of Belgium) keeps his memory alive even today. De Man became famous with his Labour Plan to fight the economic depression of the $1930 \mathrm{~s}$ in order to avoid the victory of fascism, as had occurred in I 933 in Germany, where De Man had been teaching from 1927 to I933. In 1940, however, De Man opted to collaborate with the Nazi occupier. He was a close political advisor to the king, who decided to stay in Belgium after the capitulation of the Belgian army and was willing to play a political role in a Nazi-dominated Europe. In December I94I, by which time it had become clear that there was no prominent political role for De Man possible, he moved to France, and later to Switzerland. He never returned to Belgium, where he had been convicted for political collaboration in March 1947. De Man died in a car accident in 1953.

De Man's political-ideological trajectory moved from the left wing of the Belgian Workers Party to the extreme right. De Man started as a leftist critic of Belgian reformism, but soon became a party official in workers' education. He served as an officer in the Belgian army in World War I and made a major contribution to the revision of Marxism in the I920s. In the I930s, his Labour Plan marked the start of a turn to political authoritarianism after a deceptive period as a minister (De Man became Minister of Finance, which is exceptional for a social democrat in Belgium). De Man distanced himself from socialist internationalism in favour of a socialisme national in the late I930s - leading to sharp conflicts with the classic reformists in the party, especially Emile Vandervelde (president of the Second International) - to end up as an ally of the Nazi occupier, who would, De Man believed, finally bring the victory of socialism. This remarkable ideological trajectory did not preclude the fact that De Man considered himself a socialist throughout his life.

In this biography, Jan Willem Stutje analyses the political trajectory of De Man in relation to his personal life story. For this well-written book, the author has consulted the relevant archives in Belgium and abroad and, remarkably, had access to De Man's personal statesecurity file. He has integrated the findings of the relevant literature (including older publications) written in Dutch as well as in French, avoiding the language bias often present in publications on Belgian history. Sources, especially De Man's autobiographies, are analysed critically.

Although De Man has already been researched extensively, this book is an eye-opener, revealing new facts and insights and offering keys to understand his peculiar political trajectory. De Man's authoritarianism and elitism, which has been described from an ideological 
perspective, especially for the late I930s, was also a part of his personality, as was his concern for his self-representation at a public as well as at a private level. Stutje shows how De Man used his published memoires for immediate political objectives and to deal with his political opponents, wiping out essential parts of his life story that no longer fitted the image he wanted to present of himself. Although De Man originated from an Antwerp liberal bourgeois family, he wanted to appear to be a member of the working class, or as someone rejecting bourgeois values and a bourgeois lifestyle, presenting himself as an ascetic person. This representation conflicted with the reality of De Man's life: he was a familiar figure in some bourgeois circles and was acquainted with the codes of high culture. He was, moreover, attached to well-paid positions and symbols of personal wealth. This biography makes clear why De Man turned out to be unsuccessful as a politician: his authoritarianism generated conflicts, he wrote off partners he no longer needed or had had a conflict with, and had difficulties forging alliances and finding partners. In contrast to the image he ascribed himself as a hard-working minister determined to fight unemployment in the second half of the I930s, he was not really persistent in realizing his political ideas. His assessment of the political situation was often inadequate, as appears from his faith that the king would put into practice his political plans in 1940 and that he would be politically rehabilitated after the war, or from his assessment of the policy of the military administration in Belgium in World War II.

This book also offers a new perspective on De Man's ideological profile and the origins of some of his ideas. De Man was not free of anti-Semitism, his ideas for workers' education were inspired by social Darwinism, and when teaching in Frankfurt he considered the "anti-capitalist" wing of the Nazi Party (Gregor Strasser) a possible ally for social democrats in forging an anti-capitalist front. This early flirt with fascism was no coincidence, as appears from the admiration expressed in his correspondence with Mussolini in 1930. More generally, De Man's ideological sources were on the right, rather than on the left, of the political spectrum: Oswald Spengler is a clear example. In the Belgian context, he was inspired in the late nineteenth century by Lodewijk De Raet's elitist ideas of "Vlaamse volkskracht" ["Flemish people's power"], a reaction and an alternative to the emerging socialism. De Man idealized the organic Flanders, originating in the Middle Ages, as compared to the Belgian capitalist bourgeois society of his time. Stutje questions the originality of the Labour Plan, by tracing it back to a project expounded by the Russian-German trade-union economist Wladimir Woytinsky.

Stutje's mastery of the history of the international socialist labour movement and his relative "outsider position" in Belgian historiography makes this book particularly interesting and relevant. Stutje not only analyses in-depth the impact of De Man's international experiences for his position in Belgian politics, he also considers De Man as an exponent of European or international trends and evolutions. De Man's cultural critique of historical materialism is part of a broader tendency in Marxist thinking after World War I, labelled by Perry Anderson as "Western Marxism", implying a shift from economy and politics to culture in the context of the failure of a socialist revolution after World War I.

On some points, this excellent book may lend itself to criticism, however. Stutje's treatment of the trials by the Military Tribunal, tasked with punishing collaborators after I944, might have been more elaborate. Alongside some terminological inaccuracies, an analysis of the strategy of the public prosecutor fails to adequately address the question of how the crime of political collaboration was constructed. Article i i 8 bis of the Penal Code defined political collaboration in general terms, which left considerable room for discretion on the part of magistrates. Political concepts such as populism and corporatism are not 
clearly defined. Stutje states that De Man collaborated in I940, without relinquishing the heritage of social democracy (p. 267). This thesis can be doubted if we look at political ideology: the mainstream of Belgian social democracy defended parliamentary democracy in the I930s and distanced itself from fascism and Nazism. Likewise, one can question Stutje's argument, based on a German source of September 1940, that De Man had a considerable influence on some trade-union leaders since they had supported his corporatist ideas before the war. The socialist trade union was initially reluctant to adopt corporatist ideas (which were promoted by the Catholic competitor). It was only in 1939 that, at a special congress, a majority accepted a type of corporatism that left room for strikes and was compatible with parliamentary democracy; this was, of course, not the case under Nazi occupation. No single socialist trade-union leader had accepted in the I930s the kind of authoritarian corporatism advocated by De Man in 1940.

This biography shows that De Man was, in many respects, not in line with mainstream classic Belgian reformism. Striking in this respect is the absence of anti-clericalism (a feature of Belgian social democracy): this book shows that De Man was in close contact with many Catholics, but mostly with Catholics from the extreme right, not with the Catholic labour movement. This was in line with De Man's general political orientation to count on the elites, not on mass organization, to achieve political and societal change.

Dirk Luyten

State Archives of Belgium/CegeSoma Luchtvaartsquare, 29, 1070 Brussels, Belgium

E-mail: dirk.luyten@arch.be doi:10.1017/S002085901900066X

\section{Newsinger, John. Hope Lies in the Proles. George Orwell and the Left. Pluto Press, London 20I 8. vi, I 86 pp. £75.00. (Paper: $\mathfrak{£}_{12}$ 2.99.)}

Orwell's place in the firmament of political discourse has never been in doubt, though which particular ideological constellation shows his luminosity to best effect remains debatable. Writers on Orwell, said Bernard Crick, who wrote the first detailed biography of Orwell, always claim the writer as one of their own. In fact, there was no problem: it was perfectly clear that Orwell was actually a Tribunite socialist pure and simple, just like Crick himself. That John Newsinger clearly recognizes Orwell as a fellow left-wing socialist is clear from the book's title, but this is no obstacle to the emergence of a clear-sighted and copiously referenced account of the many eccentricities and contradictions in Orwell's short career. Newsinger's adds greatly to our knowledge of the development of Orwell's relationship to left-wing groups in Britain, especially the Communist Party of Great Britain and the Independent Labour Party, as well as to the Labour Party itself, particularly after it assumed government in 1945. Newsinger's approach is thematic rather than chronological. He begins with Orwell's trip to the north of England in 1936 and his discovery of that alien tribe the British working class, whose value system he comes to equate with what he takes to be genuine or democratic socialism, as opposed to ethical socialism (about which neither Orwell, nor Newsinger has much to say) or communism and scientific socialism. Newsinger pursues Orwell to Barcelona where, attached to the Workers' Party of Marxist Unification (POUM) militia, he declared that he had gone to 